\title{
Analisis Strategi Pengelolaan Keuangan dan Strategi Keberlanjutan Usaha Kerajinan Genteng Pejaten di Masa Pandemi Covid-19 (Studi Kasus di UD. Surya Indah, Desa Pejaten, Tabanan)
}

\author{
Gusti Ayu Triana Indra Lestari ${ }^{1 *}$, Gusti Ayu Ketut Rencana Sari Dewi? iD \\ ${ }^{12}$ Jurusan Ekonomi dan Akuntansi, Universitas Pendidikan Ganesha, Singaraja, Bali \\ *trianaindralestari@gmail.com ${ }^{1 *}$
}

\section{Abstrak}

Penelitian ini bertujuan untuk menganalisis strategi pengelolaan keuangan dan strategi keberlanjutan usaha kerajinan genteng pejaten di masa covid-19 pada UD. Surya Indah, Desa Pejaten, Tabanan. Penelitian ini menggunakan pendekatan kualitatif dan akan diuraikan metode penelitian yaitu studi kasus penelitian. Sumber data pada penelitian ini adalah data primer dan data sekunder. Data yang diperoleh selanjutnya dianalisis dengan teknik analisis data yaitu pengumpulan data, reduksi data, penyajian data dan penarikan kesimpulan. Hasil penelitian ini menyatakan bahwa (1) strategi pengelolaan keuangan pada UD. Surya Indah menggunakan sistem petty cash dengan metode fluktuasi (berubah-ubah) (2) sistem pengelolaan tersebut belum efektif untuk mengontrol pengelolaan keuangan perusahaan, maka dari itu peneliti berkontribusi untuk membantu dalam penyusunan SAK EMKM, (3) upaya yang dilakukan UD. Surya Indah untuk dapat mempertahankan usahanya dengan memperhatikan aspek perencanaan modal, proses produksi bahan baku, pemasaran dan pelanggan, teknologi yang digunakan, tenaga kerja yang dimiliki, serta forward looking.

Kata Kunci: Strategi Pengelolaan Keuangan, Strategi Keberlanjutan Usaha

\begin{abstract}
This research aims to analyze financial management strategies and strategies for the sustainability of the Pejaten tile craft business during the covid-19 period at UD. Surya Indah, Pejaten Village, Tabanan. This research uses a qualitative approach and will describe the research method, namely research case studies. Sources of data in this study are primary data and secondary data. The data obtained were then analyzed by data analysis techniques, namely data collection, data reduction, data presentation and drawing conclusions. The results of this study state that (1) the financial management strategy at UD. Surya Indah uses a petty cash system with a fluctuating method (2) the management system is not yet effective in controlling the company's financial management, therefore researchers contribute to assisting in the preparation of SAK EMKM, (3) efforts made by UD. Surya Indah to be able to maintain its business by paying attention to aspects of capital planning, raw material production process, marketing and customers, technology used, workforce owned, and forward looking.
\end{abstract}

Keywords: Financial Management Strategy, Sustainability Strategy

\section{Pendahuluan}

Pada akhir tahun 2019, dunia diguncang dengan virus mematikan yang disebut dengan Corona Virus Disease 2019 atau disingkat dengan covid-19 dan pertama kali ditemukan di kota Wuhan, Tiongkok (China). Merebaknya virus ini berdampak terhadap sektor perekonomian yang mengakibatkan terjadinya krisis ekonomi di berbagai negara di seluruh dunia, termasuk Indonesia. Krisis ekonomi seperti saat ini juga pernah terjadi pada tahun 1998 dan tahun 2008 yang menimbulkan banyak sekali masalah yang kompleks (Fatwitawati, 2018). Peristiwa krisis ekonomi saat ini membuat banyak perusahaan besar mengalami

$\begin{array}{ll}\text { History: } & \text { Publisher: Undiksha Press } \\ \text { Received: August } 2021 & \text { Licensed: This work is licensed under } \\ \text { Revised: Oktober } 2021 & \text { a Creative Commons Attribution 3.0 License } \\ \text { Accepted: November } 2021 & \\ \text { Published: November } 2021 & \end{array}$


kebangkrutan atau gulung tikar, namun hanya UMKM (Usaha Mikro, Kecil, dan Menengah) yang mampu bertahan pada krisis ekonomi yang terjadi saat itu (Suci, 2017) Menurut Soetjipto (2020) dalam perekonomian Indonesia, Usaha Mikro, Kecil, dan Menengah (UMKM) adalah kelompok usaha yang memiliki jumlah paling besar. Selain itu, kelompok ini terbukti tahan terhadap berbagai macam goncangan krisis ekonomi.

Usaha Mikro, Kecil, dan Menengah yang disingkat dengan UMKM telah memberikan kontribusi yang cukup besar terhadap perekonomian Indonesia terbukti dengan UMKM Indonesia berdedikasi sebesar 53,3\% dari total PDB (Produk Domestik Bruto) nasional, sementara sisanya yaitu sebesar 46,7\% merupakan partisipasi dari sektor usaha besar. Menurut Hardiansyah (2018) terdapat tiga alasan penting yang mendasari bahwa UMKM dapat menjadi sektor bidang ekonomi yang mampu menyokong perekonomian negara berkembang seperti Indonesia, yaitu (1) kinerja UMKM cenderung lebih baik dalam menghasilkan tenaga kerja yang produktif; (2) sebagai bagian dari dinamikanya, UMKM sering mencapai peningkatan produktivitasnya melalui inovasi dan perubahan teknologi; (3) karena sering diyakini bahwa UMKM memiliki keunggulan dalam hal fleksibilitas daripada usaha besar. Selama ini UMKM telah membuktikan kemampuannya bertahan dalam situasi ekonomi yang sulit. Sebagian besar UMKM belum berhubungan langsung dengan sektor keuangan domestik, apalagi global.

Situasi tersebut menyebabkan UMKM selama ini mampu bertahan terhadap krisis keuangan global seperti pada saat ini dan tahun 1998. Berdasarkan keunggulan UMKM dalam menyerap tenaga kerja lebih banyak dan juga mampu mempercepat proses pemerataan sebagai bagian dari pembangunan, sudah selayaknya UMKM dilindungi dengan UU dan peraturan yang terkait dalam kegiatan operasional dan pengembangannya. Menurut UUD 1945 kemudian dikuatkan melalui TAP MPR NO. XVI/MPR-RI/1998 tentang Politik Ekonomi dalam rangka Demokrasi Ekonomi, Usaha Mikro, Kecil, dan Menengah perlu diberdayakan sebagai bagian integral ekonomi rakyat yang mempunyai kedudukan, peran, dan potensi strategis untuk mewujudkan struktur perekonomian nasional yang makin seimbang, berkembang, dan berkeadilan (Djatmiko \& Pudyastiwi, 2020). Namun pada kenyataanya dikarenakan kondisi pandemi wabah virus corona yang terjadi sekarang, tidak jarang UMKM khususnya dibidang industri kecil yang gagal dalam usahanya dikarenakan berbagai faktor baik itu dari sisi kelemahan permodalan, belum menerapkan sistem pengelolaan keuangan yang baik sesuai dengan standar sistem keuangan akuntansi, kurangnya inovasi atau pemasaran dan masih lemahnya pengetahuan akan teknologi.

Salah satu UMKM di Bali yaitu pada Desa Pejaten merupakan desa yang terkenal akan sentral industri kerajinan tanah liatnya. Kerajinan dari tanah liat tersebut digunakan untuk membuat genteng yang cukup berkembang dan terkenal. Kerajinan yang terkenal di Desa Pejaten ini adalah kerajinan genteng yang hampir semua mayoritas penduduknya memiliki usaha genteng. Tetapi saat ini usaha genteng di Desa Pejaten juga terkena dampak pandemi covid-19. Usaha kerajinan genteng di Desa Pejaten ini banyak mengalami penurunan omset dikarenakan jarang adanya pembangunan yang dilakukan pada keadaan sekarang ini sehingga menyebabkan terhentinya atau terhambatnya proses produksi penjualan genteng dan bahkan menurut observasi awal di lapangan sampai ada yang gulung tikar akibat dari wabah virus corona ini yang diakibatkan karena kurangnya strategi pengelolaan keuangan yang dilakukan oleh pemilik usaha dan lemahnya dari sisi permodalan, pemasaran produk, kualitas sumber daya manusia, tenaga kerja dan teknologi.

UD.Surya Indah merupakan salah satu UMKM pengerajin genteng yang ada di Desa Pejaten. Menurut observasi awal yang sudah dilakukan, usaha genteng di UD.Surya Indah masih beroperasi pada saat pandemi sekarang ini. Pada awalnya, pemilik usaha yang bernama 
Ibu Suwandari (49 tahun) melakukan usaha kerajinan genteng menggunakan sistem "MLM (Multi Level Marketing)" yang berjalan sekitar 13 tahun dari tahun 1995 sampai dengan 2008, setelah itu pemilik memberanikan diri untuk membuka perusahaan sendiri pada tahun 2008 yang saat itu terjadi krisis moneter di Indonesia. Usaha kerajinan genteng pada UD. Surya Indah sudah berjalan sekitar 13 tahun sampai sekarang, meskipun pada saat ini kendala yang dihadapi perusahaan adalah perubahan atau penurunan hasil produksi dikarenakan era pandemi covid-19.

Strategi pengelolaan keuangan dalam suatu usaha sangat penting dilakukan karena untuk mengendalikan pengeluaran, guna biaya pengeluaran tetap terkontrol. Pengelolaan keuangan pada usaha genteng UD. Surya Indah ini masih terbilang sangat sederhana, pencatatannya hanya sebatas mencatat pemasukan dan pengeluaran biaya operasional perusahaan. Sejatinya sistem pencatatan keuangan tersebut belum efektif untuk mengontrol pengelolaan keuangan perusahaan. Pemilik tidak menerapkan penyusunan laporan keuangan sesuai standar akuntansi dikarenakan format yang benar dirasakan sulit untuk dipahami dan dimengerti jika tidak diimbangi dengan pelatihan penyusunan laporan keuangan.

Maka dari itu peneliti bermaksud untuk memberikan kontribusi dalam hal membantu untuk penyusunan laporan keuangan yang sesuai dengan Standar Akuntansi Keuangan Entitas Mikro, Kecil, dan Menengah (SAK EMKM) sehingga nantinya dapat digunakan oleh UD. Surya Indah untuk membuat laporan keuangan usahanya sendiri. Selain itu dalam usaha sangat penting untuk mempertahankan keberlanjutan usaha yang dikarenakan setiap usaha selalu lebih memperhatikan suatu kondisi yang berpotensi merugikan perusahaan tersebut untuk mengantisipasi kemungkinan adanya kebangkrutan. Permasalahan yang terjadi yaitu bagaimana strategi pengelolaan keuangan yang dilakukan perusahaan serta bagaimana strategi dalam upaya mendukung keberlanjutan usaha kerajinan genteng pada UD. Surya Indah di era pandemi serta bagaimana penyusunan laporan keuangan yang sesuai dengan Standar Akuntansi Keuangan Entitas Mikro, Kecil, dan Menengah (SAK EMKM).

Salah satu teori yang mendukung pada penelitian ini adalah teori keberlanjutan usaha. Pada teori ini menjelaskan bahwa keberlanjutan adalah kemampuan suatu perusahaan untuk mempertahankan tingkat produksinya yang dibentuk oleh alam dalam kurun waktu jangka panjang. Keberlanjutan dapat diartikan sebagai sebuah kondisi disaat perusahaan memiliki kecukupan dana untuk menjalankan dan mengembangkan usahanya. Terdapat enam karakteristik utama dalam pendefinisian keberlanjutan, yaitu : a.asset-based, yaitu memulai dari mempertimbangkan aset yang ada sekarang kemudian menekankan defisiensinya. b.engages diverse stakeholders, yaitu mengikutsertakan stakeholder dari berbagai kalangan berdasarkan saling hormat, gotong royong, fleksibel dan proses pengambilan keputusan yang terbuka. c. express values, yaitu mengungkapkan nilai-nilai yang telah diadopsi secara formal oleh warga sekitar. d. Integrating, yaitu menjelaskan hubungan isu. e. forward looking, yaitu fokus pada perubahan masa depan jangka panjang dan bukan evaluasi dari masa lampau. f. distributional, yaitu bekerja dengan distribusi yang pantas bagi sumber daya dan kesejahteraan, bukan hanya untuk generasi sekarang tetapi juga untuk generasi mendatang.

Menurut M. Ridwan dalam (Hadiyanti, 2017) strategi adalah kebijakan dan keputusan kunci yang digunakan oleh manajemen yang memilik dampak besar pada kinerja keuangan. Kebijakan dan keputusan ini biasanya melibatkan komitmen sumber daya yang penting dan tidak dapat diganti dengan mudah. Sedangkan perencanaan strategi adalah untuk memungkinkan suatu perusahaan memperoleh, seefisien mungkin, kedudukan paling akhir yang dapat dipertahankan dalam menghadapi pesaing-pesaingnya. Jadi strategi perusahaan 
merupakan upaya mengubah kekuatan perusahaan yang sebanding dengan cara yang paling efisien (Hadiyanti, 2017).

Menurut (Puspitaningtyas, 2017) pengelolaan keuangan usaha berbasis akuntansi sangat penting untuk diterapkan. Pada dasarnya, setiap kegiatan usaha yang didalamnya terdapat transaksi keuangan perlu menerapkan pencatatan akuntansi. Penerapan pencatatan akuntansi akan membuat pelaku usaha dapat mengetahui kondisi keuangan usahanya (misalnya, dapat mengetahui arus kas usahanya, dapat mengetahui pendapatan usahanya, dan dapat mengetahui beban-beban usahanya). Dalam penelitian (Diyana, 2017) pengelolaan keuangan itu perlu diterapkan oleh pelaku UMKM yang diharapkan akan mengurangi resiko kerugian usaha. Saran dalam pengelolaan keuangan UMKM : a. memisahkan uang miliki pribadi dan uang usaha, b. membuat perencanaan pembelanjaan uang, c. membuat buku catatan, d. menghitung keuntungan, e. memutar arus kas, f. melakukan pengendalian terhadap harta, utang, dan modal, g. menyisihkan keuntungan untuk pengembangan usaha.

Menurut IAI dalam SAK EMKM (2016:) Entitas Mikro, Kecil, dan Menengah (EMKM) merupakan entitas tanpa akuntabilitas publik yang signifikan, yang memenuhi definisi serta kriteria usaha mikro, kecil, dan menengah sebagaimana diatur dalam peraturan perundang-undangan yang berlaku di Indonesia, setidaktidaknya selama dua tahun berturutturut. Laporan keuangan entitas meliputi : 1. laporan posisi keuangan pada akhir periode, 2. laporan laba rugi, 3. catatan atas laporan keuangan (CaLK).

Secara umum, tujuan dari penelitian ini yaitu untuk mengetahui strategi pengelolaan keuangan dan strategi keberlanjutan usaha yang diterapkan pada UD. Surya Indah untuk bisa bertahan pada saat pandemi covid-19 dan berkontribusi dalam hal membantu menyusun laporan keuangan usaha genteng UD. Surya Indah sesuai Standar Akuntansi Keuangan Entitas Mikro Kecil dan Menengah (SAK EMKM). Manfaat dalam penelitian ini yaitu diharapkan dapat memberikan kontribusi dalam memperbaiki manajemen dan kebijakan dalam pengelolaan usaha dan dijadikan acuan bagi pemilik dalam jenis usaha yang sama untuk bisa bertahan di masa krisis ekonomi.

\section{Metode}

Metode penelitian yang digunakan pada penelitian ini adalah metode penelitian kualitatif dengan metode pengumpulan datanya yaitu observasi, wawancara, dokumentasi, dan studi pustaka, dimana peneliti akan melakukan observasi ke lapangan dan mengumpulkan data-data yang nantinya akan dianalisis berdasarkan pengamatan dan pengetahuan peneliti. Penelitian ini dilakukan pada usaha genteng UD. Surya Indah di Desa Pejaten, Kecamatan Kediri, Kabupaten Tabanan. Sumber data yang digunakan terdiri dari data primer dan data sekunder. Informan yang ditetapkan pada penelitian ini meliputi : pemilik usaha genteng yaitu Bapak Wayan Suatra dan Ibu Gusti Ayu Putri Suwandari, Putu Yudi sebagai anak dari pemilik dan penerus usaha genteng, pelanggan dan karyawan UD. Surya Indah. Metode dan teknik analisis data yang digunakan adalah dengan melakukan pengumpulan data yaitu wawancara, observasi dan dokumentasi untuk mendapatkan data yang valid, setelah itu dilakukan reduksi data untuk dapat menggambarkan suatu permasalahan, kemudian dilakukan penyajian data dalam bentuk hubungan antar kategori, uraian singkat ataupun bagan, dan terakhir didapatkan penarikan kesimpulan dari penelitian. Uji keabsahan yang digunakan adalah uji triangulasi metode dan uji triangulasi sumber data.

\section{Hasil dan Pembahasan}

Strategi adalah kebijakan dan keputusan yang digunakan oleh manajemen yang memiliki dampak besar pada kinerja keuangan. Pandemi covid-19 mengakibatkan terjadinya 
krisis ekonomi dan menjadi ancaman serius sebagian besar UMKM, tetapi meskipun begitu banyak pula UMKM yang masih tetap bertahan ditengah pandemi dan ini pasti didasari dengan manajemen usaha yang baik khususnya manajemen keuangan perusahaan. Strategi pengelolaan keuangan yang dilakukan UD. Surya Indah adalah dengan membuat perencanaan atau menciptakan usaha lain dengan ekspansi bisnis yang matang dan menciptakan target pasar baru, kemudian pada saat pandemi seperti sekarang melakukan restrukturisasi bisnis dengan meminjam kredit bank, untuk kebijkakan yang diberikan oleh pihak bank yaitu suku bunga yang rendah, perpanjangan jangka waktu kredit, pengurangan tunggakan bunga dan pokok kredit untuk membantu menambah biaya kegiatan operasional perusahaan. Selanjutnya usaha genteng UD. Surya Indah ini mengelola dana cadangan yang sudah ditabung dari hasil keuntungan penjualan genteng tersebut, memiliki utang usaha yang tidak melebihi asset, dan dengan pengelolaan keuangan yang disiplin.

Pencatatan pengelolaan keuangan yang disiplin tersebut menggunakan sistem pengelolaan keuangan Petty Cash dengan metode dana fluktuasi (berubah-ubah) dikarenakan pengeluaran untuk biaya operasional tersebut selalu berubah karena pasang surutnya harga bahan baku. Secara teorinya dana kas kecil adalah dana kas untuk pengeluaran yang jumlahnya relatif kecil dengan frekuensi relatif sering untuk melaksanakan kegiatan pengeluaran kas yang rutin baik tunai maupun kredit dan tidak efektif bila menggunakan cek sedangkan jika dana kas kecil berada di bank perlu otoritas lagi untuk penarikan dananya. Pembentukan awal kas kecil pada UD. Surya Indah dilakukan oleh bagian keuangan yaitu Ibu Suwandari dan Bapak Wayan Suatra dengan mempertimbangkan pengeluaran yang akan dilakukan seperti membeli bahan baku dan bahan pembantu, serta keperluan lainnya. Sehingga nantinya hal tersebut akan berpengaruh terhadap kegiatan operasional perusahaan. Pada teorinya sistem dana berubah atau fluctuating fund system merupakan suatu dana Petty Cash yang tersedia pada pemegangan kas kecil dan jumlahnya tidak tetap dan biasanya pengisian uang ke dalam Petty Cash tidak dikaitkan dalam jangka waktu tertentu. Pengisian tersebut dilakukan sewaktu-waktu yaitu jika persediaan uang dalam Petty Cash dirasakan sudah menipis. Pada UD. Surya Indah pengisian uang kas ke dalam Petty Cash ditentukan oleh jangka waktu yaitu selama satu minggu, karena setiap hari pegawai tersebut memproduksi genteng jadi bahan baku tersebut cepat habis dan harus dibeli kembali, yang dibuktikan dengan hasil wawancara dengan Ibu Suwandari selaku pengelola keuangan pada usaha ini pada 28 April 2021 menyatakan :

"pengeluaran untuk dana operasional setiap minggu gek, dan dananya tersebut selalu berubah-ubah dikarenakan harga bahan baku kadang naik kadang turun jadi tidak menentu"

Pada UD. Surya Indah pengelolaan keuangan dilakukan oleh bagian keuangan yaitu hanya Ibu Suwandari jadi tidak ada campur tangan dari pihak manapun untuk menjaga keamanan dan efisiensi dari penyelewengan atau penyalahgunaan keuangan. Adapun Standard Operating Prosedur pengelolaan Petty Cash pada UD. Surya Indah adalah sebagai berikut : 


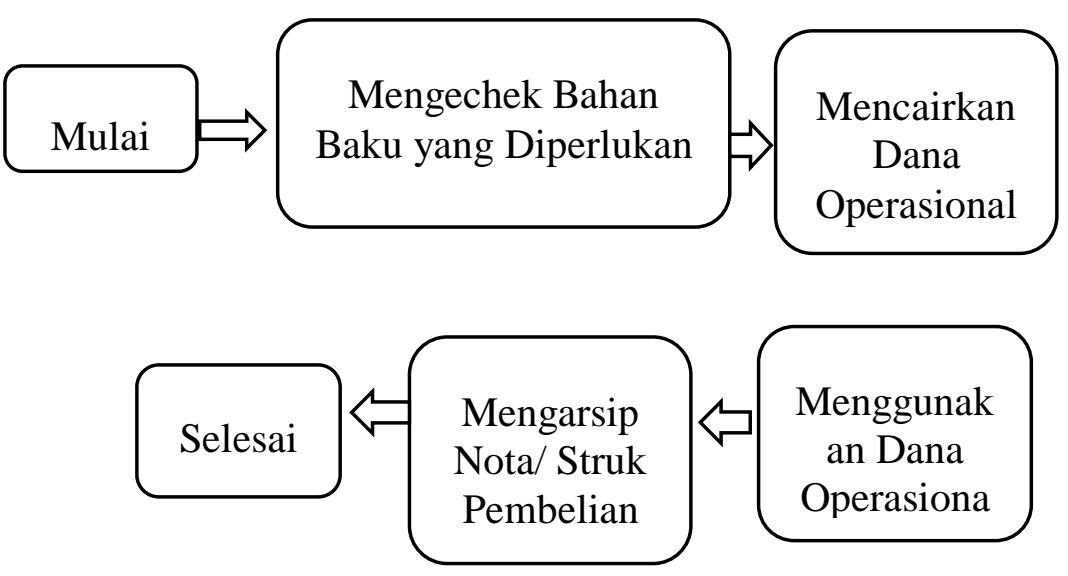

Gambar 1. Prosedur Pengelolaan Petty Cash

(Sumber : Diolah, 2021)

Penjelasan :

1. Sebelum mencairkan dana, Ibu Suwandari selaku pengelola di bagian keuangan mengecheck bahan baku apa saja yang diperlukan agar mengetahui berapa besaran dana yang harus dicairkan.

2. Setelah itu mencairkan dana operasional di ATM dengan sejumlah dana yang diperlukan untuk membiayai operasional usaha genteng seperti membeli sambuk, membeli tanah liat, paras dan biaya yang lainnya.

3. Kemudian mengarsipkan struk pembelian dan bukti-bukti transaksi pemakaian Petty Cash untuk mengontrol keluar masuknya dana perusahaan.

Dokumen yang digunakan dalam sistem dana kas kecil pada UD. Surya Indah adalah cek, jadi jika pembeli tidak memungkinkan untuk membayar secara tunai, pembeli akan membayar dengan menggunakan cek. Untuk mengontrol supaya tidak terjadi pemborosan kas tersebut, pemilik melakukan pengendalian internal dengan mencatat semua pengeluaran yang diperlukan, mengecek kembali sebelum membeli bahan baku, menyimpan nota pembelian untuk nantinya akan dilakukan croschek kembali kesesuaian jurnal dan nota, dan keuntungan atau laba yang didapatkan akan sebagian ditabung untuk mengantisipasi jika terjadi kekurangan modal dimasa depan.

UD. Surya Indah selama ini mencatat dan mengelola keuangannya dengan menggunakan pencatatan keuangan akuntansi yang sederhana seperti menggunakan sistem Petty Cash untuk mengontrol keuangannya dan belum menerapkan pencatatan sesuai standar akuntansi. Pada sistem ini hanya mencatat pengeluaran dan pemasukan jurnal pada jurnal, tetapi sejatinya sistem pencatatan keuangan tersebut belum efektif untuk mengontrol pengelolaan keuangan perusahaan. Ibu Gusti Ayu Putri Suwandari tidak menerapkan penyusunan laporan keuangan sesuai standar akuntansi dikarenakan format yang benar dirasakan sulit untuk dipahami dan dimengerti jika tidak diimbangi dengan pelatihan penyusunan laporan keuangan, dibuktikan dengan hasil wawancara pada tanggal 28 April 2021 menyatakan:

"ten buat laporan keuangan akuntansi nike gek, karena semua ibu yang mengelola keuangan sendiri, ribet gek, ibu nggak ngerti juga gimana laporan keuangan akuntansi nike. Cuma pencatatan buku kecil saja gek, kalau keuntungan ibu perkiraan saja 1 kali bakar genteng berapa untungnya" 
Pernyataan yang telah diungkap narasumber berkaitan dengan penelitian (Puspitaningtyas, 2017) yang menyatakan bahwa pelaku UMKM seringkali beranggapan bahwa akuntansi kurang bermanfaat bagi usahanya, sebenarnya pelaku UMKM telah memiliki pengetahuan tentang akuntansi, akan terapi mereka cenderung masih menjadikan kerumitan sebagai suatu alasan untuk tidak melakukan pencatatan akuntansi dalam mengelola keuangannya dikarenakan kerumitan tersebut tidak sebanding dengan skala usahanya yang dinilai masih relative kecil.

Maka dari itu peneliti bermaksud untuk memberikan kontribusi atau membantu dalam hal penyusunan laporan keuangan yang sesuai dengan Standar Akuntansi Keuangan Entitas Mikro, Kecil, dan Menengah (SAK EMKM) sehingga nantinya dapat digunakan oleh UD. Surya Indah untuk membuat laporan keuangan usahanya sendiri. Adapun format laporan keuangan yang dibuat yaitu : Laporan Posisi Keuangan (Neraca), Laporan Laba/Rugi, dan Catatan Atas Laporan Keuangan.

Menurut hasil penelitian terdahulu dari (Nurlaila, 2018) menyatakan laporan laba rugi entitas dapat mencakup akun-akun pendapatan, beban keuangan dan beban pajak. Entitas menyajikan akun dan bagian dari akun dalam laporan laba rugi jika penyajian tersebut relevan untuk memahami kinerja keuangan entitas. Laporan Laba rugi pada UD. Surya Indah dijelaskan pada tabel 1 dibawah ini :

Tabel 1. Laporan Laba Rugi UD. Surya Indah

\section{UD. SURYA INDAH \\ LAPORAN LABA RUGI \\ 31 DESEMBER 2020}

\begin{tabular}{l|l|l}
\hline PENDAPATAN & & \\
\hline Penjualan & Rp. 652.000 .000 & \\
\hline TOTAL PENDAPATAN & & Rp. 625.000.000 \\
\hline HARGA POKOK PENJUALAN & Rp. 359.572.000 & \\
\hline Harga Pokok Penjualan & & (Rp. 359.572.000) \\
\hline TOTAL HARGA POKOK PENJUALAN & & \\
\hline BEBAN-BEBAN & Rp. 6.000 .000 & \\
\hline Beban Listrik \& Air & Rp. 162.000 .000 & \\
\hline Beban Gaji & Rp. 4.200 .000 & \\
\hline Beban Bensin & Rp. 4.800 .000 & \\
\hline Beban Peny. Peralatan & Rp. 71.500 .000 & \\
\hline Beban Peny. Bangunan & Rp. 68.000 .000 & \\
\hline Beban Peny. Kendaraan & & (Rp. 316.500.000) \\
\hline TOTAL BEBAN & & Rp. 397.910.000 \\
\hline Ikhtisar Laba Rugi & & Rp. 85.610.000) \\
\hline Ikhtisar Biaya Produksi & & Rp. 288.228.000 \\
\hline LABA RUGI SEBELUM PAJAK & & Rp. 286.978.000 \\
\hline Beban Pajak & & \\
\hline LABA RUGI SETELAH PAJAK & & \\
\hline
\end{tabular}

Berdasarkan Laporan Laba Rugi Usaha Genteng pada UD. Surya Indah yang dijelaskan pada tabel 4.3 dapat dilihat bahwa laba setelah pajak sebesar Rp. 286.978.000, sementara 
harga pokok penjualan sebesar Rp. 359.572.000 dan total penjualan pada periode Desember 2020 sebesar Rp. 652.000.000. Beban usaha yang timbul dalam usaha genteng pada UD. Surya Indah periode Desember 2020 sebesar Rp. 316.500.000.

Menurut IAI dalam SAK EMKM (2016) Laporan posisi keuangan menyajikan informasi tentang aset, liabilitas, dan ekuitas entitas pada akhir periode pelaporan. Laporan Posisi Keuangan (Neraca) adalah laporan yang menggambarkan posisi keuangan suatu entitas pada saat tertentu, yang disajikan per tanggal tertentu, misalnya per tanggal 31 Desember 2020. Laporan Posisi Keuangan (Neraca) Usaha Genteng Pada UD. Surya Indah yang dijelaskan pada tabel 2 di bawah ini :

Tabel 2. Laporan Posisi Keuangan (Neraca) Pada UD. Surya Indah

\begin{tabular}{|c|c|c|c|}
\hline \multicolumn{4}{|c|}{$\begin{array}{c}\text { UD. SURYA INDAH } \\
\text { LAPORAN POSISI KEUANGAN } \\
\text { 31 DESEMBER } 2020\end{array}$} \\
\hline \multicolumn{2}{|l|}{ ASET } & \multicolumn{2}{|l|}{ LIABILITAS } \\
\hline \multicolumn{2}{|l|}{ Aset Lancar : } & \multicolumn{2}{|l|}{ Liabilitas Jangka Pendek : } \\
\hline Kas & Rp. 181.154 .000 & Utang Usaha & Rp. 25.000 .000 \\
\hline Piutang & Rp. 340.000 .000 & $\begin{array}{l}\text { Total Liabilitas } \text { Jangka } \\
\text { Pendek }\end{array}$ & Rp. 25.000.000 \\
\hline Persediaan Bahan Baku & Rp. $\quad 9.900 .000$ & Ekuitas : & \\
\hline Persediaan Bahan Pembantu & Rp. 570.000 & Modal Pemilik & Rp. 333.370.000 \\
\hline Persediaan BDP & $\begin{array}{ll}\text { Rp. } & 10.860 .000 \\
\end{array}$ & Laba & Rp. 286.978.000 \\
\hline Persediaan Barang Jadi & $\begin{array}{ll}\text { Rp. } & 70.464 .000\end{array}$ & Total Ekuitas & Rp. 620.348.000 \\
\hline Total Aset Lancar & Rp. 612.948 .000 & & \\
\hline \multicolumn{4}{|l|}{ Aset Tetap : } \\
\hline Tanah & Rp. 110.000 .000 & & \\
\hline Peralatan Pabrik & $\begin{array}{ll}\text { Rp. } & 16.000 .000 \\
\end{array}$ & & \\
\hline $\begin{array}{ll}\text { Akumulasi } & \text { Penyusutan } \\
\text { Peralatan } & \end{array}$ & $\begin{array}{ll}\text { Rp. } & 9.600 .000)\end{array}$ & & \\
\hline Bangunan & $\begin{array}{ll}\text { Rp. } & 110.000 .000\end{array}$ & & \\
\hline Penyusutan & (Rp. 143.000.000) & & \\
\hline Kendaraan & $\begin{array}{ll}\text { Rp. } & 85.000 .000\end{array}$ & & \\
\hline $\begin{array}{ll}\text { Akumulasi } & \text { Penyusutan } \\
\text { Kendaraan } & \end{array}$ & (Rp. 136.000.000) & & \\
\hline Total Aset Tetap & Rp. $\quad 32.400 .000)$ & & \\
\hline TOTAL ASET & Rp. 645.348 .000 & TOTAL LIABILITAS & Rp. 645.348.000 \\
\hline
\end{tabular}

Berdasarkan tabel 4.4 yang menjelaskan Laporan Posisi Keuangan pada UD. Surya Indah periode Desember 2020, diketahui total asset yang terdiri dari asset tetap dan asset lancar sebesar Rp. 645.348.000, sebanding dengan jumlah liabilitas ditambah dengan ekuitas yaitu liabilitas sebesar Rp. 25.000.000 dan ekuitas sebesar Rp. 620.348.000.

Selain strategi pengelolaan keuangan dilakukan untuk bisa bertahan disaat pandemi, perlu juga dilakukan strategi keberlanjutan usaha yang nantinya digunakan untuk prospek masa depan. Prinsip keberlanjutan usaha sangat penting bagi pemilik badan usaha untuk mengantisipasi kemungkinan adanya potensi kebangkrutan, karena kebangkrutan menyangkut terjadinya biaya-biaya baik biaya langsung maupun tidak langsung. Usaha kerajinan genteng yang dibangun oleh pemilik Bapak Wayan Suatra dan Ibu Gusti Ayu Putri Suwandari merupakan usaha turun temurun dan industri kecil yang dimulai pada tahun 1995. Keberadaan dari usaha genteng ini telah memberikan dampak positif bagi keluarga Bapak 
Wayan Suatra, dikarenakan melalui usaha genteng ini dapat mensejahterakan anggota keluarganya dan cukup dalam memenuhi kebutuhan sehari-hari. Usaha genteng ini dikategorikan ke dalam usaha kecil karena memiliki aset antara Rp. 50.000.000 sampai Rp. 500.000.000 dan masih menggunakan tenaga manusia, sehingga mampu menyerap tenaga kerja dengan menyediakan lapangan pekerjaan.

Keberlanjutan usaha adalah kemampuan suatu sistem untuk mempertahankan tingkat produksinya yang dibentuk oleh alam dalam kurun waktu jangka panjang dengan tujuan sebagai maksimasi dari kesejahteraan badan usaha yang merupakan nilai sekarang badan usaha itu terhadap prospek masa depannya. Hal ini sesuai atau sependapat dengan hasil penelitian terdahulu dari (Priyani \& Ikhwana, 2016) menyatakan bahwa persaingan yang ketat membuat perusahaan harus mampu bertahan dan berkembang. Persaingan tersebut tidak lagi melihat dari produk yang dihasilkan melainkan keseimbangan antara produk yang dihasilkan dengan kinerja perusahaan yang dilakukan melalui perbaikan dan langkah yang diambil pada tahap berikutnya. Prinsip keberlanjutan usaha sangat penting bagi pemilik badan usaha untuk mengantisipasi kemungkinan adanya potensi kebangkrutan, karena kebangkrutan menyangkut terjadinya biaya-biaya baik biaya langsung maupun tidak langsung.

Dari hasil wawancara yang dilakukan peneliti, upaya yang dilakukan pemilik dalam mempertahankan keberlanjutan usaha genteng di masa pandemi adalah dengan memperhatikan beberapa aspek yaitu :

\section{Perencanaan Modal}

Dari hasil wawancara tersebut pemilik menyebutkan bahwa untuk dapat bertahan pada keadaan sekarang, usaha mereka memiliki modal pinjaman kredit KUR dari bank sebesar Rp. 25.000.000. Modal sebesar Rp. 25.000.000 tersebut juga ditambahkan dari kas yang dimiliki usaha genteng tersebut untuk menunjang kegiatan operasional usaha pada saat pandemi saat ini. Hal tersebut sependapat dengan hasil penelitian (Hadiyanti, 2017) menyatakan modal awal adalan untuk pengembangan usaha di masa depan yang berasal dari modal sendiri atau pinjaman kredit bank. Fasilitas perbankan sebagai penyalur dana merupakan kebijakan dari pemerintah untuk memberdayakan UMKM. Dengan sumber modal dari pinjaman bank dan modal sendiri pemilik berharap dapat mengembangkan usahanya pada masa pandemi, melakukan pengendalian keuangan dan tidak boros dalam pengeluaran, mengambil sedikit keuntungan dari hasil penjualan untuk ditabung dan sebagian diputar kembali untuk membeli bahan baku serta perlengkapan produk genteng.

\section{Proses Produksi Bahan Baku}

Bahan baku merupakan faktor utama yang diperlukan dalam usaha kerajinan genteng karena dengan bahan baku akan diolah menjadi barang jadi yang sesuai dengan produk usaha dan akan dipasarkan kepada pelanggan. Kebutuhan bahan baku suatu usaha dapat naik atau turun tergantung kondisi dan permintaan dari pelanggan. Bahan baku utama untuk menghasilkan produk genteng adalah tanah liat dan paras (pasir) dan bahan baku pembantu (penolong) adalah sambuk. Kualitas dan ketersediaan sumber bahan baku tanah liat dan bahan baku pembantu sambuk sangat dibutuhkan untuk dapat mempertahankan keberlanjutan usaha genteng tersebut. Menurut hasil wawancara, pemilihan tanah liat dari daerah Gadungan, Tabanan karena memiliki karakteristik yang berbeda dari tanah liat daerah lain yaitu dari segi tektsurnya yang lebih bagus dan tanah galian sawahnya yang lebih baik agar terjaga kualitas genteng pada UD. Surya Indah ini. Menjaga kualitas produk dan tidak 
mengecewakan para pelanggan adalah hal yang paling diutamakan pada usaha genteng UD. Surya Indah ini, dan juga Bapak Wayan Suatra selaku pemilik genteng mengaku bahwa :

"untuk bahan baku tanah liat pemilik membeli tanah liat galian di daerah Gadungan seharga Rp. 50.000.000 setelah itu dijual kepada pelanggan dan termasuk kepada usaha genteng UD. Surya Indah. Usaha bahan baku atau ekspansi bisnis yang juga dilakoni oleh pemilik usaha dilakukan untuk bisa mempertahankan usahanya pada keadaan krisis seperti sekarang dan menghindari terjadinya kebangkrutan usaha"

\section{Pemasaran dan Pelanggan}

Dari hasil wawancara yang telah dilakukan peneliti, pemilik usaha genteng telah melakukan promosi usaha genteng dengan cara mencari relasi bisnis dari hasil dahulu pernah melakukan bisnis usaha genteng dengan sistem "MLM (Multi Level Marketing)", dari sistem mulut ke mulut (Word of Mount), dan juga melakukan pemasaran dengan sistem kerja sama kepada beberapa agen mitra yaitu toko bangunan diluar daerah Tabanan seperti daerah Gianyar, Ubud, Bangli, Payangan, Badung, Denpasar, dan Negara. Kemudian membentuk target pasar baru dengan membuat ekspansi bisnis, seperti bisnis bata press, bahan baku genteng, bisnis tenda, dan dari bisnis baru inilah pemilik Bapak Wayan Suatra dan Putu Yudi juga ikut mempromosikan produk genteng tersebut. Dari hasil wawancara tersebut sejalan dengan hasil dari penelitian (Fauzi, 2018) menyatakan bahwa cara untuk mengembangkan usaha adalah dengan meningkatkan pasar yang lebih luas sehingga produk usaha lebih dikenal diluar daerah, serta meningkatkan kualitas produk agar dapat menghasilkan produk yang baik untuk siap dipasarkan. Faktor untuk menentukan kepuasan pelanggan yaitu pemilik usaha harus memperhatikan kualitas pelayanan dan kualitas produk. Kualitas pelayanan merupakan tingkat keunggulan yang diharapkan dan pengendalian atas tingkat keuanggulan tersebut untuk memenuhi harapan pelanggan. Apabila pelayanan yang diterima dan diharapkan sesuai harapan pelanggan, maka kualitas pelayanan dipersepsikan baik dan terciptanya kepuasan pelanggan. Kepuasan pelanggan merupakan hal yang sangat diutamakan pada usaha genteng UD. Surya Indah dan selalu menetapkan prinsip "pembeli/pelanggan adalah raja", karena pelanggan yang puas nantinya bukan hanya membeli produk sesuai dengan kebutuhan pelanggan tetapi mereka juga akan melakukan rekomendasi pada orang-orang terdekat untuk membeli produk usaha tersebut. Dari hasil wawancara tersebut bahwa kualitas pelayanan dan kualitas produk pada usaha genteng UD. Surya sangat memuaskan kebutuhan konsumen, disamping karena pemilik Bapak Wayan Suatra sangat menjaga kepercayaan pelanggan dengan mengawasi secara ketat pada proses menaikkan barang agar tidak terjadi kerusakan dan hasil produk tersebut sesuai dengan harapan pelanggan, pemilik juga saling menjaga komunikasi antar pelanggan agar tidak terjadi salah paham antara satu sama lain. Hal tersebut sudah membuktikan prinsip dari usaha genteng milik Bapak Wayan Suatra ini yaitu "pembeli/pelanggan adalah raja".

\section{Teknologi yang Digunakan}

Pemakaian teknologi yang digunakan dalam proses produksi genteng pada UD. Surya Indah yaitu dengan menggunakan alat mesin press atau mesin cetak genteng dan mesin molen, sebab alat tersebut umumnya memang seperti itu di semua pengusaha genteng. Kemudian proses produksinya tersebut masih menggunakan bantuan cahaya matahari dan ketersediaan bahan pembantu sambuk untuk proses pembakaran genteng. Penggunaan teknologi tersebut dapat membantu pekerjaan karyawan UD. Surya Indah karena dibantu dengan menggunakan mesin cetak atau press dan molen, sehingga dapat menghemat waktu 
dan dan tenaga serta memproduksi banyak genteng dalam sehari. Selain dapat mempersingkat waktu bekerja, penggunaan teknologi tersebut dapat meningkatkan upah gaji karyawan UD. Surya Indah tersebut dikarenakan peningkatan produk genteng yang dihasilkan dengan menggunakan mesin molen dan mesin cetak (press) genteng

\section{Tenaga Kerja yang Dimiliki}

Pada usaha genteng UD. Surya Indah memiliki jumlah tenaga kerja beranggotakan sebanyak 9 orang. Tenaga kerja pada usaha genteng ini adalah tenaga borongan yang ratarata bekerja pada usaha ini adalah sekeluarga yaitu bapak, ibu, dan anak. Sistem kerja pada karyawan usaha genteng UD. Surya Indah tergantung ketersediaan bahan baku yang telah disediakan oleh pemilik usaha tersebut. Kenyamanan tenaga kerja yang diberikan oleh pemilik Bapak Wayan Suatra adalah dengan menerapkan sistem kerja dari jam 08.00 pagi16.30 dan istirahat selama 1 jam. Untuk sistem libur tersebut apabila ada keperluan atau hari raya dan harus pulang kampung secara otomatis akan meliburkan diri. Usaha yang baik adalah usaha yang mensejahterakan karyawannya, dari hasil wawancara tersebut dapat disimpulkan bahwa karyawan tersebut telah diberikan hak atau kenyaman oleh pemilik usaha genteng UD. Surya Indah. Dari hasil bekerja pada usaha genteng UD. Surya Indah pun karyawan mengaku bisa menyekolahkan anaknya, membeli motor, mememnuhi kebutuhan sehari-hari, bahkan membangun rumah di kampung halamannya.

\section{Forward Looking}

Fokus terhadap perubahan masa depan (forward looking) menjadi tugas dari pada semua usaha, termasuk usaha genteng UD. Surya Indah. Hal ini dilakukan agar usaha genteng tersebut mampu bertahan dan berkembang ditengah keadaan pandemi seperti sekarang ini. Cara yang harus ditempuh agar usaha tetap bisa bertahan dan berkembang adalah dengan melakukan restrukturisasi. Restrukturisasi adalah strategi atau perubahan untuk melakukan penataan ulang yang nantinya akan berdampak kepada kinerja perusahaan di masa depan. Strategi restrukturisasi dilakukan untuk mencari jalan keluar akan permasalahan yang dihadapi oleh perusahaan saat. Dalam hal ini, restrukturisasi yang dilakukan UD. Surya Indah untuk fokus terhadap perubahan masa depan adalah restrukturisasi kredit. Restrukturisasi kredit dilakukan usaha genteng UD. Surya Indah untuk mendapatkan modal yang akan digunakan dalam menjalankan usaha genteng tersebut agar tetap bertahan dan berkembang ditengah pandemi dan kinerja perusahaan menjadi lebih sehat.

Aspek tersebut dipertahankan agar usaha genteng yang telah dimulai dari tahun 1995 tetap berlanjut dalam memproduksi genteng secara turun temurun.

\section{Simpulan dan Saran}

Bersumber dari hasil dan pembahasan yang telah dipaparkan sebelumnya, maka ditarik kesimpulan yaitu strategi pengelolaan keuangan yang dilakukan UD. Surya Indah adalah dengan membuat perencanaan dengan ekspansi bisnis yang matang dan menciptakan target pasar baru, melakukan restrukturisasi bisnis dengan meminjam kredit bank, memiliki utang usaha yang tidak melebihi asset, dan dengan pengelolaan keuangan yang disiplin. Pencatatan pengelolaan keuangan yang disiplin tersebut menggunakan sistem pengelolaan keuangan Petty Cash dengan metode dana fluktuasi (berubah-ubah) dikarenakan pengeluaran untuk biaya operasional tersebut selalu berubah karena pasang surutnya harga bahan baku. Tetapi sejatinya sistem pencatatan keuangan tersebut belum efektif untuk mengontrol pengelolaan 
keuangan perusahaan. Maka dari itu peneliti bermaksud untuk memberikan kontribusi atau membantu dalam hal penyusunan laporan keuangan yang sesuai dengan Standar Akuntansi Keuangan Entitas Mikro, Kecil, dan Menengah (SAK EMKM) sehingga nantinya dapat digunakan oleh UD. Surya Indah untuk membuat laporan keuangan usahanya sendiri. Selain itu untuk bisa bertahan pada saat pandemi perlu dilakukan strategi keberlanjutan usaha yang digunakan untuk prospek masa depan. Upaya yang dilakukan UD. Surya Indah untuk dapat mempertahankan usahanya di tengah pandemi adalah dengan memperhatikan beberapa aspek yaitu perencanaan modal, proses produksi bahan baku, pemasaran dan pelanggan, teknologi yang digunakan, tenaga kerja yang dimiliki, dan fokus pada perubahan masa depan. Aspek tersebut dipertahankan agar usaha genteng yang telah dimulai dari tahun 1995 tetap berlanjut dalam memproduksi genteng secara turun temurun.

Berdasarkan hasil dari penelitian, adapun beberapa saran yang dapat penulis berikan terkait dengan penelitian ini adalah (1) Bagi UD. Surya Indah diharapkan terdapat pemisahan uang pribadi dan uang usaha dan menerapkan penyusunan laporan keuangan sesuai dengan Standar Akuntansi Keuangan Entitas Mikro, Kecil, dan Menengah (SAK EMKM) agar dapat mengontrol pengelolan keuangan perusahaan. (2) Bagi peneliti selanjutnya diharapkan dapat mengembangkan penelitian selanjutnya dengan memperluas daerah lokasi penelitian hingga seluruh usaha genteng yang ada di Desa Pejaten tersebut dengan menggunakan teori TOWS analysis untuk meningkatkan keberlanjutan usaha dimasa depan.

\section{Daftar Pustaka}

BPS. 2011. Produk Domestik Bruto. (online). Diakses 12 oktober 2020. (http://www.bps.go.id/index.php?news=730)

Diyana, I. Y. F. (2017). Analisis Pengelolaan Keuangan Usaha Mikro Kecil dan Menengah. Skripsi.

Fatwitawati, R. (2018). Pengelolaan Keuangan Bagi Usaha Mikro Kecil Menengah (UMKM) di Kelurahan Airputih Kecamatan Tampan Kota Pekanbaru. Seminar Hasil Pengabdian Kepada Masyarakat, 225-229.

Fitriyani, I., Sudiyarti, N., \& Fietroh, M. N. (2020). Strategi Manajemen Bisnis Pasca Pandemi Covid-19. Indonesian Journal of Social Sciences and Humanities, 1(2), 87-95.

Hadiyanti, L. M. (2017). Analisis Pengembangan Industri Kecil Kerajinan Genteng Dalam Upaya Meningkatkan Kesejahteraan Pengrajin Prespektif Ekonomi Islam (Studi Pada Masyarakat Desa Pujorahayu Kec. Negeri Katon Kab. Pesawaran). Skripsi, 01(01), 1689-1699.

Hardiyansyah. 2011. Kualitas Pelayanan Publik. Yogyakarta : Gava Media

Noer, Soetjipto. 2020. Ketahanan UMKM Jawa Timur Melintasi Pandemi Covid-19. Yogyakarta : K-Media

Nurlaila. (2018). Penerapan Standar Akuntansi Keuangan Entitas Mikro Kecil dan Menengah (SAK EMKM) Pada Sukma Cipta Ceramic Dinoyo-Malang. Skripsi. 
Kuswantoro, K., \& Alfi, I. (2020). Strategi Keuangan Umkm Cilacap Menghadapi Pandemi Covid 19 (Studi Kasus Umkm Kabupaten Cilacap). Jurnal Teknologi Dan Bisnis, 2(1), 40-51. https://doi.org/10.37087/jtb.v2i1.13

Priyani, H., \& Ikhwana, A. (2016). Strategi Keberlanjutan Usaha Dodol Sarinah dengan Menggunakan Balanced Scorecard pada Pd.Sarinah Garut. Jurnal Kalibrasi, 14, $55-65$.

Puspitaningtyas, Z. (2017). Pembudayaan Pengelolaan Keuangan Berbasis Akuntansi Bagi Pelaku usaha Kecil Menengah. Jurnal Akuntansi, XXI(03), 361-372.

Rahmana, Arief. 2008. Usaha Kecil dan Menengah (UKM), Informasi Terdepan tentang Usaha Kecil Menengah, (online). Diakses 1 oktober 2011. (http://infoukm.wordpress.com)

Saleh, A. (2018). Evaluasi Pengelolaan Petty Cash Pada PT. PLN (PERSERO) UPB Sulserraba. Skripsi.

Sari, T. I. (2018). Keberlanjutan dan kontribusi industri kecil kerajinan genteng dalam meningkatkan kesejahteraan pengrajin (Studi Kasus Industri Genteng Desa Pancasan, Kec. Ajibarang, kab. Banyumas). Skripsi.

Setyahayu, Tri Gita. 2013. Sistem dan Prosedur Pengelolan Atas Kas Kecil Pada PT. Bank Pembangunan Daerah Jawa Timur Cabang Bojonegoro. Tugas Akhir. Sekolah Tinggi llmu Ekonomi Perbanas Surabaya.

Suci, Y. R. (2017). Perkembangan UMKM (Usaha Mikro Kecil Menengah) di Indonesia. Jurnal Ilmiah Cano Ekonomos, 6(1), 51-58. 